$\frac{12}{3-21-979501}$

SAND97-8228 • UC-406

$19705 x+9$

Unlimited Release

SAND- $-97-8228$

Printed January 1997

\title{
Surface Functionalization of Silica Microparticles for Capillary Electrochromatography (CEC)
}

\author{
T. J. Shepodd, Deon S. Anex, Judith L. Rognlien
}
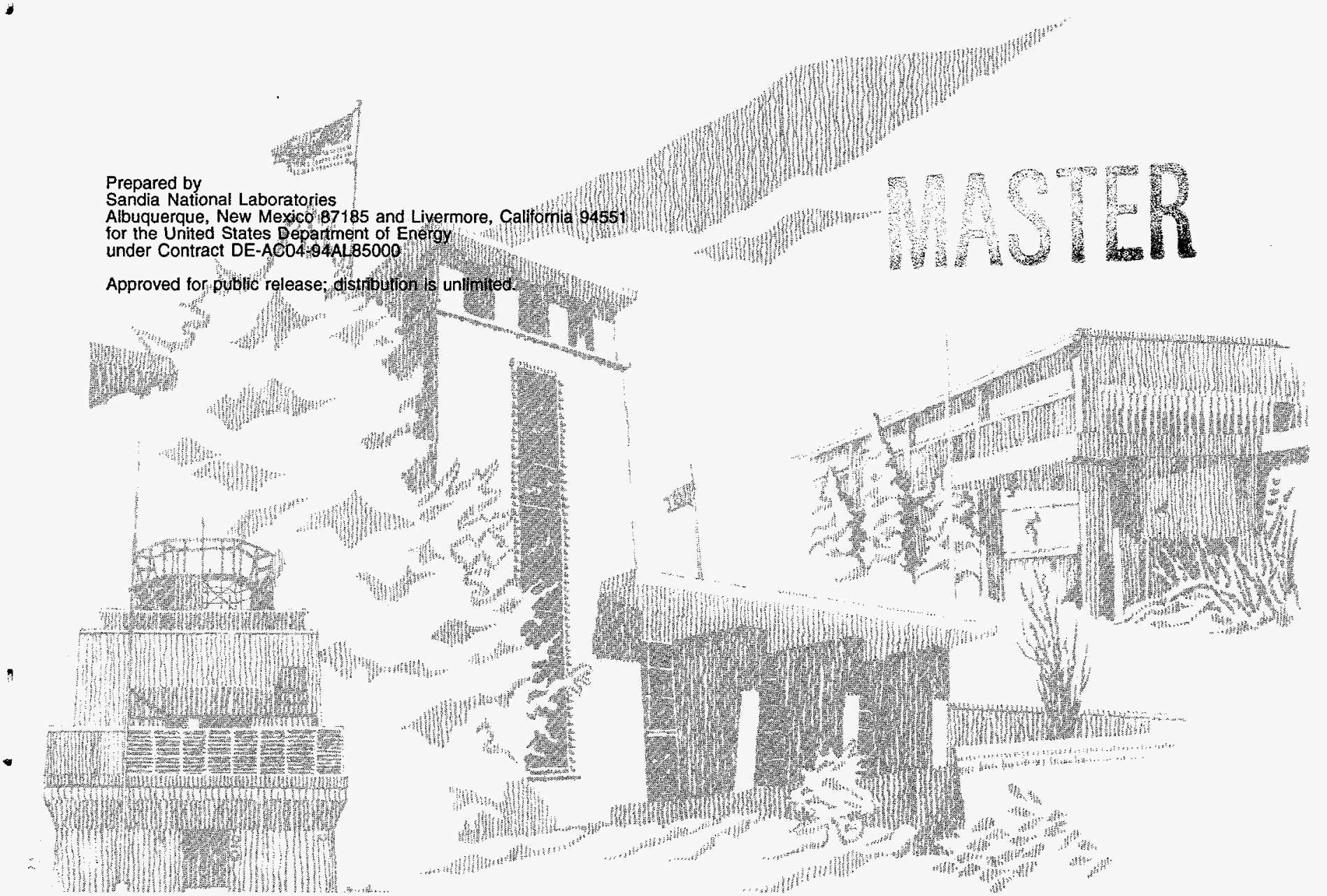
Issued by Sandia National Laboratories, operated for the United States Department of Energy by Sandia Corporation.

NOTICE: This report was prepared as an account of work sponsored by an agency of the United States Government. Neither the United States Government nor any agency thereof, nor any of their employees, nor any of the contractors, subcontractors, or their employees, makes any warranty, express or implied, or assumes any legal liability or responsibility for the accuracy, completeness, or usefulness of any information, apparatus, product, or process disclosed, or represents that its use would not infringe privately owned rights. Reference herein to any specific commercial product, process, or service by trade name, trademark, manufacturer, or otherwise, does not necessarily constitute or imply its endorsement, recommendation, or favoring by the United States Government, any agency thereof or any of their contractors or subcontractors. The views and opinions expressed herein do not necessarily state or reflect those of the United States Government, any agency thereof, or any of their contractors or subcontractors.

This report has been reproduced from the best available copy.

Available to DOE and DOE contractors from:

Office of Scientific and Technical Information

P.O. Box 62

Oak Ridge TN 37831

Prices available from (615) 576-8401, FTS 626-8401.

Available to the public from:

National Technical Information Service

U.S. Department of Commerce

5285 Port Royal Rd.

Springfield, VA 22161 


\section{DISCLAMMER}

Portions of this document may be illegible in electronic image products. Images are produced from the best available original document. 
SAND 97-8228

UC-406

Unlimited Release

Printed January 1997

\title{
SURFACE FUNCTIONALIZATION OF SILICA MICROPARTICLES FOR CAPILLARY ELECTROCHROMATOGRAPHY (CEC)
}

\author{
T. J. Shepodd \\ Materials Chemistry Department \\ Sandia National Laboratories/California \\ Deon S. Anex and Judith Rognlien \\ Combustion Chemistry Department \\ Sandia National Laboratories/California
}

\begin{abstract}
We derivitized small $(0.5-3 \mu \mathrm{m})$ silica particles by silating their surfaces with long-chain alkyl substituted silanes. These functionalized particles were packed into $100 \mu \mathrm{m}$ capillaries and used as stationary phases for capillary electrochromatography. The particles supported electroosmotic flow in mixtures of acetonitrile and aqueous buffer ( $4 \mathrm{mM}$ sodium tetraborate or $2 \mathrm{mM}$ TRIS). The columns were used to separate mixtures of organic analytes demonstrating the effectiveness of the functionalized stationary phase.
\end{abstract}




\section{ACKNOWLEDGMENTS}

The authors would like to acknowledge George Buffleben, Gary Hux, and Carolyn Childress for their assistance in the laboratory. 


\section{CONTENTS}

\section{Page}

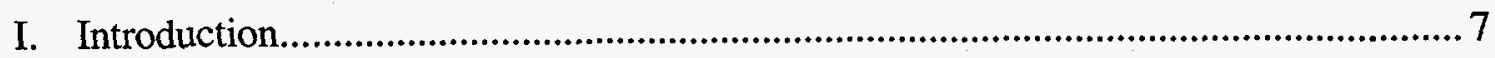

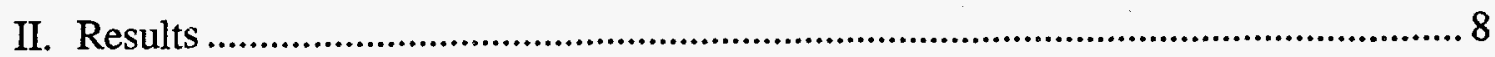

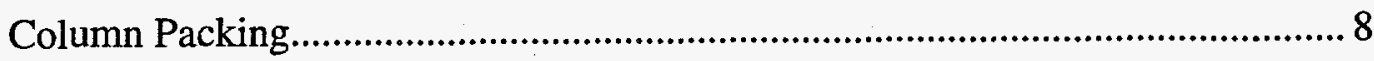

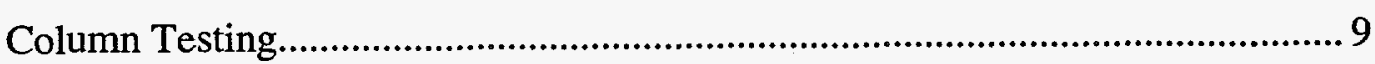

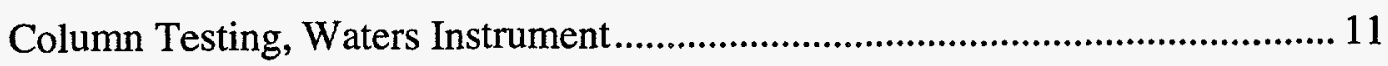

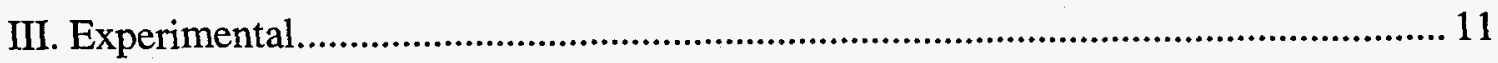

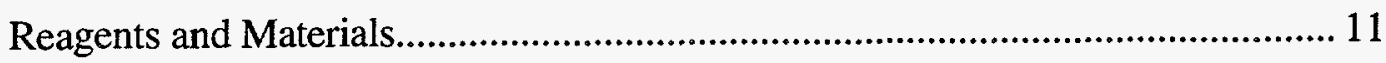

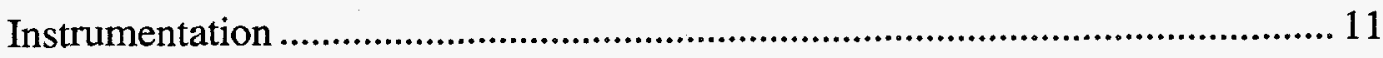

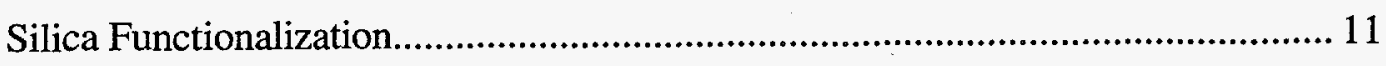

Column Preparation ...................................................................................... 12

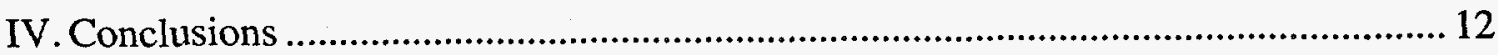

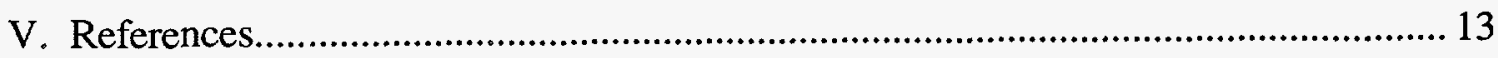




\section{SURFACE FUNCTIONALIZATION OF SILICA MICROPARTICLES FOR CAPILLARY ELECTROCHROMATOGRAPHY (CEC)}

\section{Introduction}

Capillary electrochromatography (CEC) is one example of electrokinetic separations performed in capillary columns that provide high resolution and high efficiency analyses of complex samples. 1,2 Other examples include capillary zone electrophoresis (CZE), capillary gel electrophoresis, and micellar electrokinetic capillary chromatography. CEC involves packing the capillary column with chromatographic particles. It is of considerable interest because it provides a high-efficiency universal separation technique that combines the strengths of capillary electrophoresis (CE) and high-performance liquid chromatography (HPLC).

The heart of CEC is the capillary, which is packed with an HPLC stationary phase. In reversedphase chromatography, the stationary phase is a hydrocarbon layer that is usually chemically bonded to a support. The most common support is small silica particles which are typically spherical in shape and have micron-scale diameters. The role of the stationary phase is to cause differential retention of analytes relative to a flowing mobile phase, causing them to separate as they pass through the column.

In CEC, electroosmotic flow (EOF) is used to drive the mobile phase through the columns. In HPLC, pressure is used to drive the mobile phase. EOF is voltage-driven flow that is generated at the walls of open capillaries and on the surfaces of silica particles. This flow is characterized by a plug-like velocity profile and a linear flow rate that is independent of channel diameter (down to small channels with dimensions on the order of the electrical double layer). These flow characteristics reduce the spreading of the individual analyte bands as they traverse the column and result in very high efficiency separations.

Due to the presence of the stationary phase, CEC can separate neutral species using a mechanism similar to HPLC, but CEC has significantly higher resolution than HPLC because the flow is electroosmotically driven. High-efficiency CEC enables complex chemical samples to be separated into their components and provides benefits beyond those of conventional HPLC techniques that include: (1) superior separations $\left(\sim 10^{6}\right.$ theoretical plates $\left./ \mathrm{m}\right)$; (2) small sample volumes (10 nl); (3) low solvent consumption ( $100 \mathrm{nl} / \mathrm{min})$ and low waste generation; (4) small and low-cost columns; (5) low power requirements; and (6) potential for further miniaturization using microfabrication techniques.

Electrochromatography in a packed (non-capillary) chromatographic column was initially demonstrated by Mould and Synge ${ }^{3}$ and Pretorius and coworkers. ${ }^{4}$ It was subsequently adapted to capillaries by Jorgenson and Lukacs. ${ }^{5}$ Early work in CEC utilized columns packed with particles that were $5-10 \mu \mathrm{m}$ in size. Chromatographic theory predicts the efficiency to increase as the size of the particles used for the separation is decreased. ${ }^{1}$ Hence, there has been a trend toward developing the ability to perform separations with smaller particles. As particle size becomes smaller in a packed column, the use of traditional pressure-based pumps to drive the mobile phase becomes prohibitive because of the high back pressures generated. The use of these columns for chromatography is therefore the sole province of CEC, unless extraordinary measures are taken to produce extremely high pressure (many tens of thousand psi). With decreasing particle size in $\mathrm{CEC}$, the optimum particle size for efficient separations remains an outstanding issue. 
Although a variety of research has been previously reported in CEC,5-28 of particular relevance to this work are reports of separations performed in columns packed with small $(<3 \mu \mathrm{m})$ particles because of their superior performance. Knox and Grant ${ }^{8}$ first reported the benefits of CEC using columns packed with particle sizes down to $1.5 \mu \mathrm{m}$. Yamamoto et al..$^{11}$ utilized $1.6-\mu \mathrm{m}$ octadecylsilica (ODS) particles for the separation of small organic compounds. Smith and Evans ${ }^{14}$ used a modified CEC apparatus with an external pressure applied to both the inlet and outlet reservoirs to minimize bubble formation and a column packed with $1.8-\mu \mathrm{m}_{8}$ particles. More recently, by using a combination of electric field and pressure applied to the column, Behnke et al. ${ }^{21}$ used a $15 \mathrm{~cm}$ long column packed with $1.5-\mu \mathrm{m}$ ODS particles. Also, Schmeer et al. ${ }^{22}$ have used $1.5 \mu \mathrm{m}$ particles in a CEC apparatus coupled to a mass spectrometer. In our laboratory, using high-sensitivity laser-induced fluorescence (LIF) detection, we have demonstrated high resolution CEC with $3 \mu \mathrm{m}$ porous ODS particles ${ }^{16}$ and have shown remarkable improvements in speed and efficiency when $1.5 \mu \mathrm{m}$ non-porous particles are used. ${ }^{16 a}$

In this study, we expand on our earlier work in CEC and demonstrate that CEC is possible with particles as small as $0.5 \mu \mathrm{m}$. Particles of this size are not available commercially with the appropriate coating for reversed-phase chromatography. We have obtained bare silica particles (diameters to $0.5 \mu \mathrm{m}$ ) and have bonded a $\mathrm{C}_{18}$ stationary phase to them. These were then packed into capillary columns using the electrokinetic packing technique. The columns were tested using commercial and home-built instruments using ultraviolet (UV) absorption and UV laser-induced fluorescence (LIF) detection of the separated components.

The chemistry to functionalize the silica was straightforward. ${ }^{29}$ Surface silanols of the silica beads react with silyl chlorides forming a siloxane bond and eliminating hydrogen chloride. An excess of silyl chloride and a prolonged reaction time are used so that as much of the surface becomes functionalized as possible. We used different alkyl chain lengths attached to the surface, but a variety of functionalities are commercially available to explore different solute/stationary phase interactions. We had to show that though exhaustively functionalized, the stationary phase would still have sufficient charge to support EOF.

\section{Results}

\section{Column Packing}

The first challenge in using $0.5 \mu \mathrm{m}$ particles is in preparing the packed capillary columns. Electrokinetic packing, in which the electrophoretic mobility of the particles themselves is used to drive the particles into the column, is the most efficient method available. Two factors influencing packing success of the various functionalized silica particles were solvent type and frit porosity. The solvent used routinely for our standard slurries of $3 \mu \mathrm{m}$ silica is methanol, and we began with this solvent in making slurries of our experimental functionalized silica particles. A methanol/2.9 $\mu \mathrm{m}$ NPS $\mathrm{C}_{18}$ slurry yielded successful packing; however, we experienced clumping when using methanol with the smaller $1.5 \mu \mathrm{m}$ NPS $\mathrm{C}_{18}$. We experimented with other alcohols, next trying ethanol (still had clumping), then propanol, in which the particles remained dispersed and we achieved successful packing. Butanol resulted in only loose packing, leading us to conclude that propanol was the optimal alcohol for $1.5 \mu \mathrm{m}$ NPS $C_{18}$. With $0.5 \mu \mathrm{m} \mathrm{NPS} \mathrm{C}_{18}$ we found that methanol did not facilitate dispersal of the silica beads, and propanol resulted in very minimal 
packing. For this material we achieved superior packing results by abandoning the alcohols and, instead, using our running buffer, 80:20 $\mathrm{CH}_{3} \mathrm{CN}: 4 \mathrm{mM} \mathrm{Na}_{2} \mathrm{~B}_{4} \mathrm{O}_{7}$.

While frits must be strong enough to prevent the packing slurry from passing through them, we found that we achieved our best packing results when we had fairly porous frits. In making optimal frits, we must achieve some fusing of the sintered silica frit material to the column wall, but we must also have a flow of solvent that is barely impeded in passing through the frit.

\section{Column Testing}

The shorter columns were tested using the CEC/LIF instrument described below. The first column ( $6 \mathrm{~cm}$ packed length, $14 \mathrm{~cm}$ total length, $100 \mu \mathrm{m}$ id) was packed with uncoated $0.5 \mu \mathrm{m}$ fused silica particles. This column was used to verify that EOF could be generated in a column packed with particles this small. The results of a test run are shown in Figure 1. Here the mobile phase composition is 80:20 (v/v) $\mathrm{CH}_{3} \mathrm{CN}: 4 \mathrm{mM}$ borate buffer and the column were run at $6 \mathrm{kV}$. The single peak is $10 \mathrm{nM}$ fluoranthene injected for less than 1 second at $6 \mathrm{kV}$. Since these particles are not coated with a stationary phase, the analyte is not retained and simply indicates the nature of the flow through the column. It is clear that EOF is efficiently generated in this column by the reasonable flow rate $0.7 \mathrm{~mm} / \mathrm{s}$. To fully test the utility of $0.5 \mu \mathrm{m}$ particles for CEC, it is necessary, of course, to perform a separation with particles coated with a stationary phase.

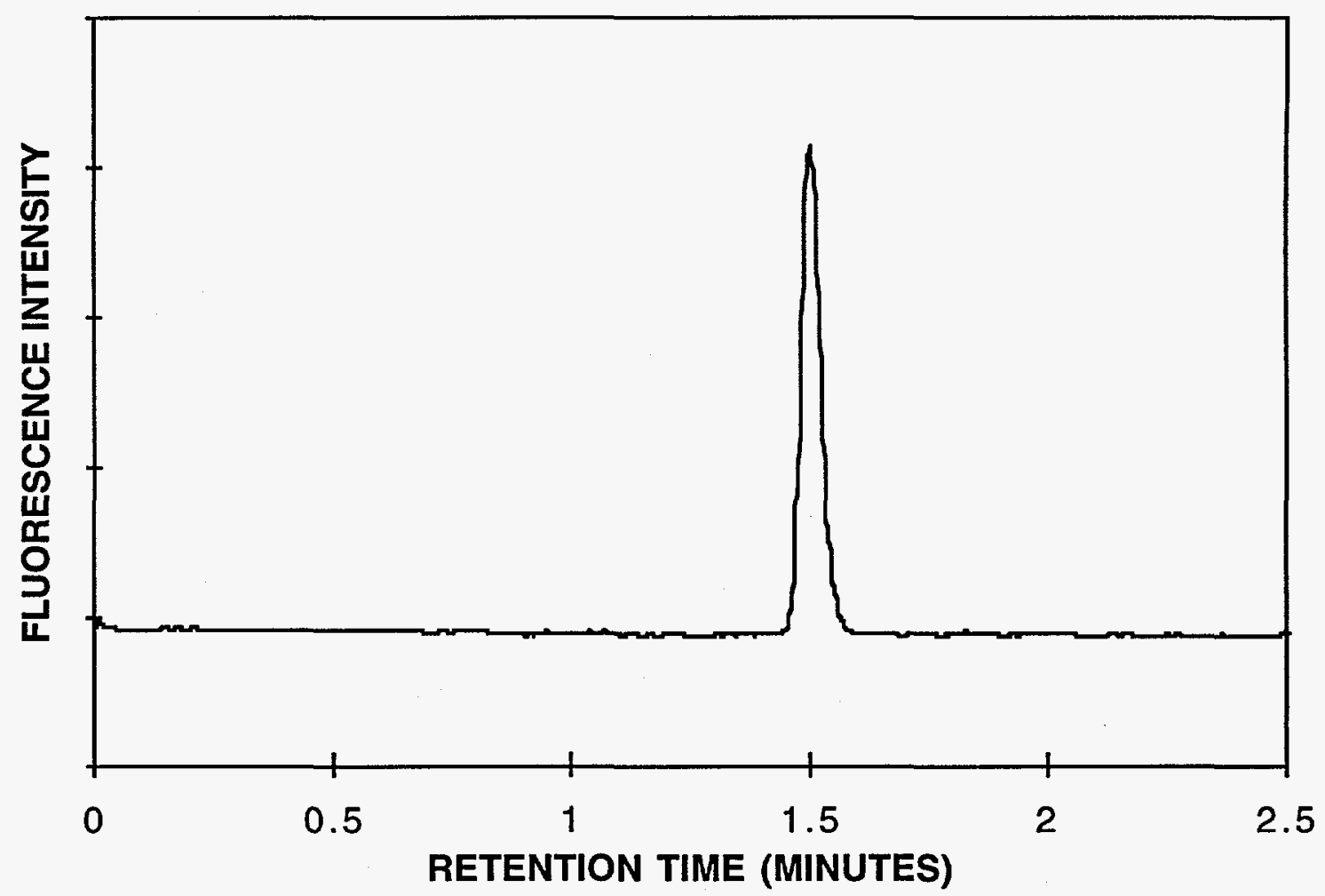

Figure 1: A single component sample (10 $\mathrm{nM}$ fluoranthene) runs on a CEC column packed with uncoated $0.5 \mu \mathrm{m}$ fused silica particles $(6 \mathrm{~cm}$ packed length, $14 \mathrm{~cm}$ total length $100 \mu \mathrm{m} \mathrm{ID}$ ). The mobile phase composition is $80: 20$ (v/v) $\mathrm{CH} 3 \mathrm{CN}: 4 \mathrm{mM}$ borate buffer, the sample was injected for less than 1 second at $6 \mathrm{kV}$, and the column was run at $6 \mathrm{kV}$. 
A separation of three compounds ( $1 \mathrm{mM}$ fluoranthene, $1 \mathrm{mM}$ naphthalene and $10 \mathrm{mM}$ pyrene) is shown in Figure 2. This column ( $24 \mathrm{~cm}$ packed length, $36 \mathrm{~cm}$ total length, $100 \mu \mathrm{m} \mathrm{ID)}$ was packed with $0.5 \mu \mathrm{m}$ particles prepared in-house with a chemically bonded $\mathrm{C}_{18}$ stationary phase. The compounds are clearly retained on the column and are separated. By measuring the widths of the peaks at half height $\left(\mathrm{w}_{1 / 2}\right)$ and their retention times $\left(\mathrm{t}_{\mathrm{r}}\right)$, the number of theoretical plates $(\mathrm{N}, \mathrm{a}$ measure of the efficiency of the chromatographic separation) can be calculated using the equation

$$
\mathrm{N}=5.54\left(\mathrm{t}_{\mathrm{r}} / \mathrm{w}_{12}\right)^{2} \text {. }
$$

This number is usually normalized to the column length and is expressed in theoretical plates per meter. For the peaks in this run the values of $\mathrm{N}$ are $1.62 \times 10^{5}, 1.53 \times 10^{5}$, and $1.46 \times 10^{5}$ theoretical plates per meter.

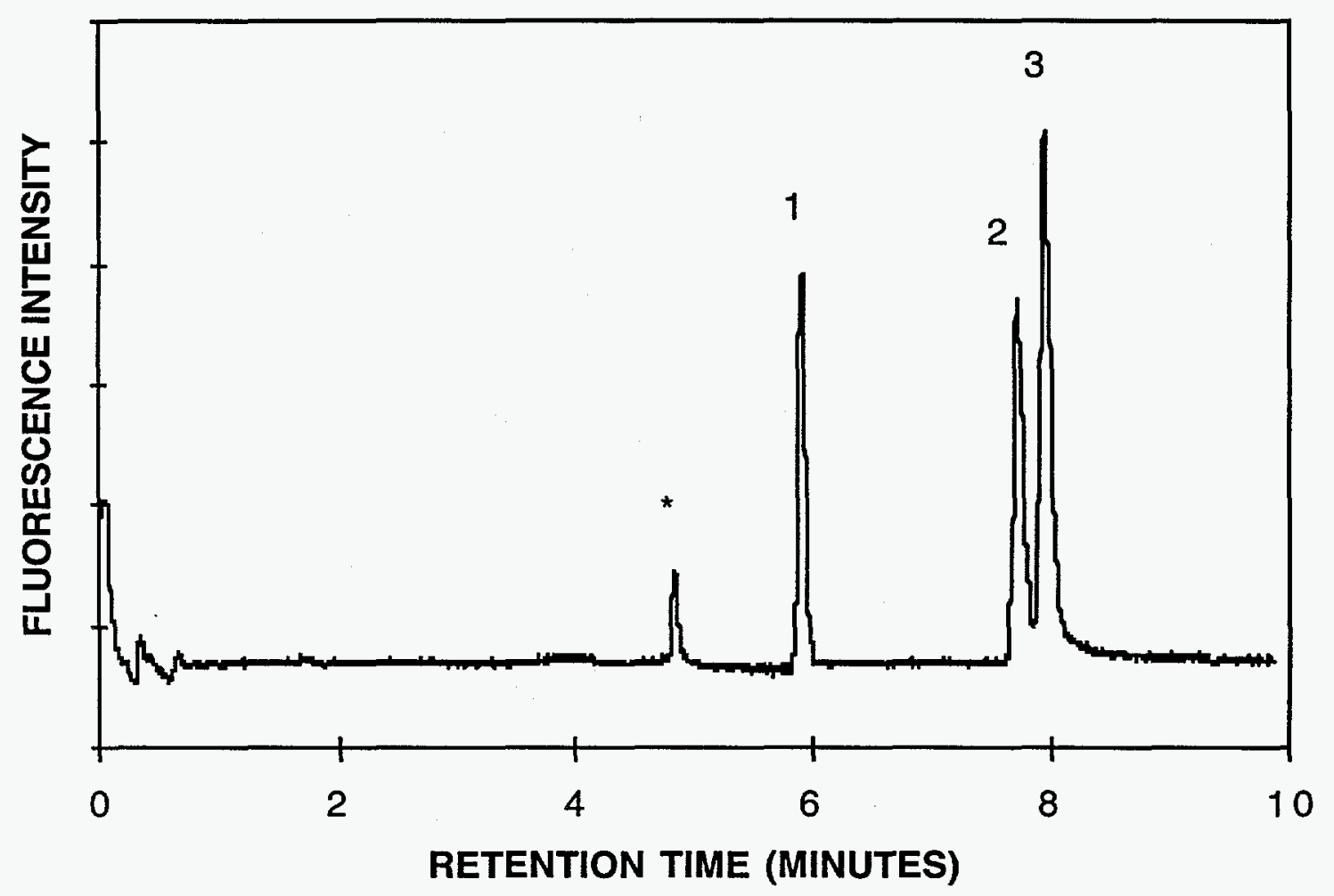

Figure 2: A separation of three compounds: (1) $1 \mathrm{mM}$ naphthalene, (2) $1 \mathrm{mM}$ fluoranthene and (3) $10 \mathrm{mM}$ pyrene. This CEC column $(24 \mathrm{~cm}$ packed length, $36 \mathrm{~cm}$ total length, $100 \mu \mathrm{m} \mathrm{ID)} \mathrm{was} \mathrm{packed} \mathrm{with} 0.5 \mu \mathrm{m}$ particles prepared in-house with a chemically bonded $\mathrm{C}_{18}$ stationary phase. The mobile phase composition is $50: 50(\mathrm{v} / \mathrm{v}) \mathrm{CH}_{3} \mathrm{CN}$ : $2 \mathrm{mM}$ TRIS buffer, the sample was injected for 1 second at $1 \mathrm{kV}$ and the column was run at $10 \mathrm{kV}$. The asterisk indicates a weakly retained impurity in the sample.

This value is lower than those obtained previously for commercial $1.5 \mu \mathrm{m}$ particles. $16 \mathrm{a}$ Simply based on particle size, it was expected that the results for the $0.5 \mu \mathrm{m}$ particles should have been significantly better. There are several possibilities for reduced performance. These include inefficient EOF in some parts of the column (due to narrow interparticle spacing with dimensions on the order of the electrical double layer) or extra-column broadening (e.g., peak broadening caused by passage through inlet or outlet frits). 


\section{Column Testing, Waters Instrument}

Of the various functionalized non-porous silica (NPS) particles, only one with the $2.9 \mu \mathrm{m}$ NPS $\mathrm{C}_{18}$ slurry was of sufficient length to run on the Waters Quanta $4000 \mathrm{CE}$ instrument. Using a detection wavelength of $214 \mathrm{~nm}$, an injection of two seconds at $10 \mathrm{kV}$ and a 15 minute, $10 \mathrm{kV}$ separation run, a sample comprising thiourea, benzyl alcohol, benzaldehyde, and naphthalene was used as a test mixture. With a standard column of $3 \mu \mathrm{m}$ ODS, the separation of the four compounds is typically achieved using a running buffer of 70:30 $\mathrm{CH}_{3} \mathrm{CN}: 4 \mathrm{mM} \mathrm{Na} \mathrm{Ba}_{4} \mathrm{O}_{7}$. However, total separation using the $2.9 \mu \mathrm{m}$ NPS $\mathrm{C}_{18}$ column was not achieved until the buffer composition had been altered to $30: 70 \mathrm{CH}_{3} \mathrm{CN}: 4 \mathrm{mM} \mathrm{Na} \mathrm{B}_{4} \mathrm{O}_{7}$. Unfortunately, with this composition, the column dried out and became unusable.

\section{Experimental}

\section{Reagents and Materials}

Non-porous, bare silica particles were obtained from Bangs Laboratories, Inc. (Carmel, IN) and the fused silica capillaries were supplied by Polymicro Technologies, Inc. (Phoenix, AZ). Sodium tetraborate, sodium phosphate, TRIS, acetonitrile (HPLC grade), toluene, octyldimethylchlorosilane, octadecyldimethylchlorosilane, and methanol were purchased from Sigma Aldrich Chemical Co. (Milwaukee, WI). Water was purified using the Ultra-Pure water system (Millipore, Milford, MA). Toluene was dried over freshly activated 4A molecular sieves. ${ }^{30}$ Mobile phases were prepared by mixing the appropriate volume of acetonitrile with the aqueous buffer followed by degassing using sonication and the application of vacuum.

\section{Instrumentation}

The shorter columns were tested on a CEC/LIF laboratory set-up described previously. ${ }^{16}, 16 \mathrm{a}$ In brief, an intracavity-doubled argon-ion laser (Coherent, Inc., Santa Clara, CA) operating at $257 \mathrm{~nm}$ was used for excitation of the PAHs. A high numerical aperture (N. A.) microscope objective (40 $\mathrm{x}$ magnification, $\mathrm{N} . \mathrm{A} .=0.85$ ) in a confocal design was used for fluorescence collection from the capillary. A variable slit and a set of filters transmitting wavelengths between $\sim 280$ and $600 \mathrm{~nm}$ were placed in between the objective and a photomultiplier tube (PMT) to minimize interference to the fluorescence signal from the capillary wall fluorescence and scattered light. A lock-in amplifier (Stanford Research Systems, Sunnyvale, CA) was used in conjunction with a chopper (operating at $250 \mathrm{~Hz}$ ) in the path of the laser beam to measure the output of the PMT. Commercial software (LabCalc, Galactic Industries Corp., Salem, NH) runs on an IBM personal computer was used for data acquisition at a rate of $1-100 \mathrm{~Hz}$.

A commercial Waters Quanta 4000 CE instrument outfitted with a UV absorption detector was used to test the longer columns. For these experiments the detector used a $214 \mathrm{~nm}$ zinc lamp UV light source, a $214 \mathrm{~nm}$ band-pass filter and a photo diode. Runs were made using the positive high-voltage power supply.

\section{Silica Functionalization}

Standard solutions $(0.1 \mathrm{M})$ of silyl chlorides were made in dry toluene. These solutions were used to functionalize the silica using the procedure that follows.

Approximately $0.5 \mathrm{~g}$ microspheres were placed in a $50 \mathrm{ml}$ round-bottom flask. A stir bar was added to the flask and the flask was attached to a Claisen adapter. One arm of the adapter was attached to a vacuum/nitrogen manifold, and the other arm was covered with a septum. A stirring 
plate was placed underneath the flask. The microspheres were allowed to dry overnight under vacuum (approx. 100 mtorr) while being stirred. - A cold-finger and trap were added to the manifold system. Approximately $25 \mathrm{ml}$ of the dry toluene was transferred to the round-bottom flask, through the septum using a canula. Vacuum was carefully applied to the suspension of microspheres, until all the solvent was gone. The toluene was added and pulled off twice more to remove trace water via the toluene/water azeotrope. The manifold was purged with nitrogen, and the cold trap removed. A dry $5 \mathrm{ml}$ syringe was used to transfer $5 \mathrm{ml}$ of the $\mathrm{C}_{18}$ in toluene solution to the sample flask. The sides of the flask were scraped down using a second magnet on the outside of the flask. The sample was allowed to react overnight under a nitrogen atmosphere. The sample was then transferred to two microcentrifuge tubes with a pipet. The tubes were then centrifuged for three to four minutes at $4000 \mathrm{rpm}$. The toluene was suctioned off using a pipet. This process was repeated until all of the sample had been added to the tubes. The coated microspheres were spun down, resuspended, and rinsed with fresh toluene three times. This process was repeated four times with isopropanol. The tubes were placed in a $50^{\circ} \mathrm{C}$ oven, and the microspheres were allowed to dry overnight. The final product remained a free flowing powder which was substantially hydrophobic. Yields were $50-75 \%$ of theoretical with the losses occurring in the many transfer steps. Spheres of $3 \mu \mathrm{m}, 1.5 \mu \mathrm{m}$, and $0.5 \mu \mathrm{m}$ diameters were functionalized with octyldimethlychlorosilane and octadecyldimethylchlorosilane.

\section{Column Preparation}

Capillary columns (100 $\mu \mathrm{m}$ inner diameter $/ 365 \mu \mathrm{m}$ outer diameter) were prepared using the electrokinetic packing procedure developed previously. ${ }^{16,31}$ Slurries of the packing materials were made by suspending $100 \mathrm{mg}$ of the solid material in $1 \mathrm{ml}$ of a solvent. Sonication was used to aid in suspension of the particles and for degassing of the solvents. Several non-porous packing materials (and the corresponding solvents for preparing the slurries) were used: $0.5 \mu \mathrm{m}$ bare silica (methanol), $0.5 \mu \mathrm{m}$ ODS (80:20 v/v CH $\mathrm{CN}_{3}: 4 \mathrm{mM} \mathrm{Na}_{2} \mathrm{~B}_{4} \mathrm{O}_{7}$ ) and $2.9 \mu \mathrm{m}$ ODS (methanol). To make the columns, an initial frit was made in one end of the column by sintering a porous plug of silica gel using a flame. The slurry was then used to electrokinetically pack the columns as described previously. ${ }^{16,31}$ The column was then attached to an HPLC pump and pressurized to 4000 to $6000 \mathrm{psi}$. A second frit consisting of fused ODS particles was made in the column to hold the particles firmly in place using a fiber-optic splicer (Fiberline IFS-2001, Preformed Line Products, Mayfield Village, $\mathrm{OH}$ ). Extraneous particles in between the second frit and the outlet of the column were then flushed out. A narrow window (a few $\mathrm{mm}$ in length) for detection was created just beyond the packed portion of the column by burning off the polyimide coating. The column was then flushed (using EOF) with the selected mobile phase before performing the separations.

\section{Conclusions}

We successfully derivitized small uniform silica particles and packed them into CEC columns. We demonstrated separation of analytes using EOF but did not achieve the number of theoretical plates that we might expect from the diameter of the particles. We consider these experiments successful, and we expect that as we learn more about the logistics of column packing and analysis parameters we will be able to improve our separation efficiencies.

This work has led to a new LDRD studying the synthesis and function of CEC stationary phases. 


\section{References}

1. H. A. Strobel, W. R. Heineman, Chemical Instrumentation: A Systematic Approach, (John Wiley and Sons, New York, 1989).

2. R. Weinberger, Practical Capillary Electrophoresis, (Academic Press, Inc., San Diego, 1993).

3. D. L. Mould, R. L. M. Synge, Analyst, 77, 964 (1952).

4. V. Pretorius, B. J. Hopkins, J. D. Schieke, J. Chromatogr., 99, 23 (1974).

5. J. W. Jorgenson, K. D. Lukacs, J. Chromatogr., 218, 209 (1981).

6. T. S. Stevens, H. J. Cortes, Anal. Chem., 55, 1365 (1983).

7. T. Tsuda, Anal. Chem., 59, 521 (1987).

8. J. H. Knox, I. H. Grant, Chromatographia, 24, 135, (1987).

9. F. M. Everaerts, A. A. A. M. van de Goor, Th. P. E. M. Verheggen, J. L. Beckers, High Res. Chromatogr., 12, 28 (1989).

10. J. H. Knox, I. H. Grant, Chromatographia, 32, 317 (1991).

11. H. Yamamoto, J. Baumann, F. Erni, J. Chromatogr., 593, 313 (1992).

12. P. Coufal, H. A. Claessens, C. A. Cramers, J. Liq. Chromatogr., 16, 3623 (1993).

13. C. Yan, D. Schaufelberger, F. Erni, J. Chromatogr., 670, 15 (1994).

14. N. W. Smith, M. B. Evans, Chromatographia, 38, 649 (1994).

15. H. Rebscher, U. Pyell, U. Chromatographia, 38, 737 (1994).

16. C. Yan, R. Dadoo, H. Zhao, R. N. Zare, D. J. Rakestraw, Anal. Chem. 67, 2026 (1995).

16a R. Dadoo, R. N. Zare, C. Yan, D. S. Anex, and D. J. Rakestraw, "Advances in Capillary Electrochromatography: Rapid and High-Efficiency Separations" Anal. Chem., in preparation.

17. R. J. Boughtflower, T. Underwood, C. J. Paterson, C. J. Chromatographia, 40, 329 (1995).

18. S. J. Lane, R. Boughtflower, C. Paterson, T. Underwood, Rapid Commun. Mass Spectrum., 9, 1283 (1995).

19. T. Eimer, K. K. Unger, T. Tsuda, Fresenius J. Anal. Chem., 352, 649 (1995). 
20. J. P. C. Vissers, H. A. Claessens, H. A., P. Coufal, J. High Res. Chromatogr., 18, 540 (1995).

21. B. Behnke, E. Grom, E. Bayer, J. Chromatogr., 716, 207 (1995).

22. K. Schmeer, B. Behnke, E. Bayer, Anal. Chem., 67, 3656 (1995).

23. F. Lelièvre, C. Yan, R. N. Zare, P. Gareil, J. Chromatogr., 723, 145 (1996).

24. M. T. Dulay, C. Yan, D. J. Rakestraw, R. N. Zare, J. Chromatogr., 725, 361 (1996).

25. C. Yan, R. N. Dadoo, R. N. Zare, D. J. Rakestraw, D. S. Anex, Anal. Chem., 66, 2726 (1996).

26. S. J. Lane, R. Boughtflower, C. Paterson, M. Morris, Rapid Commun. Mass Spectrum., 10, 733 (1996).

27. H. Rebscher, U. Pyell, Chromatographia, 42, 171 (1996).

28. H. Rebscher, U. Pyell, J. Chromatogr., 737, 171, (1996).

29. E. P. Plueddemann, Silane Coupling Agents, (Plenum Press, New York, 1982).

30. Sieves are activated at $3-25-350{ }^{\circ} \mathrm{C}$ for 5 hours and cooled in a desiccator under nitrogen. Details of the water vapor equilibrium for various molecular sieves are available in technical bulletins from UOP.

31. C. Yan, Electrokinetic Packing of Capillary Columns, U.S. Patent 5,453,163, (1993). 
UNLIMITED RELEASE

INITIAL DISTRIBUTION

MS 0188 LDRD

MS 9001 T. O Hunter, 8000

Attn: J. B. Wright, 2200

M. E. John, 8100

L. A. West 8200

W. J. McLean, 8300

R. C. Wayne, 8400

P. N. Smith, 8500

P. E. Brewer, 8800

D. L. Crawford, 8900

MS 9055 D. S. Anex, 8353 (3)

MS 9055 D. J. Rakestraw, 8353

MS 9055 F. Tully, 8353

MS 9401 M. T. Dyer, 8700

Attn: M. W. Perra, 8711

M. I. Baskes, 8712

G. J. Thomas, 8715

K. L. Wilson, 8716

W. G. Wolfer, 8717

G. A. Benedetti, 8741

M. R. Birnbaum, 8742

P. E. Nielan, 8743

MS 9403

W. A. Kawahara, 8746

MS 9403

G. M. Buffleben, 8713

MS 9403

C. K. Childress, 8713

MS 9403

T. J. Shepodd, 8713 (3)

MS 9671

J. C. F. Wang, 8713

MS 9671

G. A. Hux, 8353

J. L. Rognlien, 8353 (3)

MS 9021 Technical Communications Department, 8815 , for OSTI (10)

MS 9021 Technical Communications Department, 8815/Technical Library, MS 0899, 4414

MS 0899 Technical Library, 4414 (4)

MS 9018 Central Technical Files, 8940-2 (3) 